\title{
Maternal mortality at Gulbarga district hospital, a tertiary care centre
}

\author{
Sudha V. Biradar ${ }^{1 *}$, Rajshekhar D. Kerure ${ }^{2}$, Amaresh V. Biradar
}

\footnotetext{
${ }^{1}$ Associate Professor, Department of Obstetrics \& Gynaecology, ESIC Medical College, Gulbarga, Karnataka

${ }^{2}$ Assistant Professor, Department of Nephrology, M. R. Medical College, Gulbarga, Karnataka

${ }^{3}$ Assistant Professor, Department of Surgery, M. R. Medical College, Gulbarga, Karnataka
}

Received: 11 September 2015

Accepted: 23 September 2015

\author{
*Correspondence: \\ Dr. Sudha V. Biradar, \\ E-mail: dr_sudhabiradar@rediffmail.com
}

Copyright: () the author(s), publisher and licensee Medip Academy. This is an open-access article distributed under the terms of the Creative Commons Attribution Non-Commercial License, which permits unrestricted non-commercial use, distribution, and reproduction in any medium, provided the original work is properly cited.

\begin{abstract}
Background: Pregnancy, although being considered a normal physiological state, carries serious risk of morbidity and at times maternal death. Maternal mortality ratio (MMR) is a very sensitive index that reflects the quality of health care provided by the country to the women population. It also reflects the educational and socioeconomic state of a country as well as public health consciousness. This study was carried out to determine the causes of maternal deaths at Gulbarga district hospital, a tertiary care hospital.

Methods: This is a cohert of prospective and retrospective hospital based study of 2 years. IPD case records of maternal deaths were studied. A total of 25 maternal deaths were analyzed using percentage.

Results: In the maternal deaths studied, the leading direct causes of death were haemorrhage (32\%), followed by eclampsia (15\%). Anaemia (8\%) and cerebrovascular accidents $(9 \%)$ were the common indirect causes of maternal death in our study. Most women (72\%) died within 12 hours of admission suggesting majority patients reach the tertiary care hospital late.

Conclusions: Most of the maternal deaths were preventable by optimal antenatal, intranatal and perinatal care. Most effective intervention to reduce pregnancy related mortality is education of family planning methods and safe abortion methods, increasing the number of skilled birth attendants, reducing home births and improving emergency obstetric care (EOC).
\end{abstract}

Keywords: Maternal mortality, Post-partum hemorrhage, Eclampsia, Sepsis

\section{INTRODUCTION}

Pregnancy, although being considered a physiological state, carries risk of serious maternal morbidity and at times death. This is due to various complications occurring during pregnancy, labour and thereafter. By definition, maternal mortality is the death of any woman being pregnant or within 42 completed days of termination of pregnancy, irrespective of the duration or site of pregnancy, from any cause related to or aggravated by pregnancy, but not from accidental or incidental causes. $^{1,2}$
Maternal mortality is a ratio, and it is expressed as maternal deaths per 1lakh live births. Currently it is estimated to be 212 per lakh live births which is far above the desired goal of 100 per lakh live births as per objectives of Millennium Development Goals (MDG).

Between 1990 and 2010, maternal mortality worldwide dropped by almost $50 \%$ but still it is unacceptably high. The high number of maternal deaths in some areas reflects inequities in access to health services, and highlights the gap between rich and poor. 
Half million women worldwide are dying every year from pregnancy or childbirth related problems, a quarter of these deaths occur in India alone (Table 1).,

Maternal death has serious implications to the family, the society and nation. The event of death of mothers is only the tip of iceberg. Many women are suffering from anaemia, lack of care from the family, pre-eclampsia, eclampsia, placenta previa, postpartum haemorrhage and sepsis. ${ }^{4}$

The government of India is committed to the appalling health statistics of the rural poor which significantly contribute to the global mortality rate of mothers and children under the age of five years. ${ }^{5}$

Hence this present study was conducted to review the existing maternal mortality ratio and the causes of maternal death at a tertiary care hospital, so that corrective steps can be taken to reach the goal within the stipulated time frame as most of the deaths are preventable.

\section{METHODS}

This study is a cohert of prospective and retrospective hospital based study of 2 years from $1^{\text {st }}$ November 2012 to $31^{\text {st }}$ October 2014. IPD case records of maternal deaths were studied in detail. A total of 25 maternal deaths were analysed using percentage. Cases were distributed according to age, socio-economic status, literacy rate, areas of residence, parity, antenatal care registration, state of pregnancy at death, time of admission to death, and causes of death. The study \& data collection were carried out with the approval from the Institutional Ethical Committee.

\section{RESULTS}

Table 1: Global problem (MMR/1 lakh).

\begin{tabular}{|ll|}
\hline Country & MMR \\
\hline India & 200 \\
\hline USA & 21 \\
\hline New Zealand & 15 \\
\hline UK & 12 \\
\hline Switzerland & 8 \\
\hline France & 8 \\
\hline Srilanka & 35 \\
\hline Nepal & 170 \\
\hline
\end{tabular}

At District Hospital, Gulbarga, total no. of live births in 2 years $\left(1^{\text {st }}\right.$ Nov 2012- $31^{\text {st }}$ Oct 2014) was 43638. Number of maternal deaths in 2 years was 25 .

MMR in the present study is 57 per 1 lakh live births. Admissions of moribund cases referred from peripheral centres have inflated maternal mortality ratio.
In the present study, maximum $(68 \%)$ number of deaths were in the age group $<29$ years of $40 \%$ maternal deaths were in 19-24 years age, and $28 \%$ in 25-29 years age group (Table 2).

Table 2: Distribution of maternal deaths according to age.

\begin{tabular}{|lll|}
\hline Age (yrs.) & Number & Percentage \\
\hline$<19$ & 0 & 0 \\
\hline $19-24$ & 10 & 40 \\
\hline $25-29$ & 7 & 28 \\
\hline $30-34$ & 5 & 20 \\
\hline$>35$ & 3 & 12 \\
\hline Total & 25 & 100 \\
\hline
\end{tabular}

All mothers belonged to lower socio-economic status (Table 3). $84 \%$ of the women were illiterate and $12 \%$ had primary education (Table 4).

Table 3: Socioeconomic status.

\begin{tabular}{|lll|}
\hline S-E Status & Number & Percentage \\
\hline Upper & 0 & 0 \\
\hline Middle & 0 & 0 \\
\hline Lower & 25 & 100 \\
\hline Total & 25 & 100 \\
\hline
\end{tabular}

In the present study, maximum (88\%) women were from rural areas (Table 5) and $84 \%$ mothers had not taken any antenatal check-ups and were unbooked cases (Table 6). Out of 25 deaths, 15 mothers $(60 \%)$ were Multigravidas and $28 \%$ were primigravidas (Table 7 ). $88 \%$ deaths occurred in post-partum period of which 9 deaths occurred in immediate post-partum period (Table 8).

Table 4: Education status.

\begin{tabular}{|lll|}
\hline Education & Number & Percentage \\
\hline Illiterate & 21 & 84 \\
\hline Primary education & 3 & 12 \\
\hline Secondary education & 1 & 4 \\
\hline $\begin{array}{l}\text { Higher secondary } \\
\text { education }\end{array}$ & 0 & 0 \\
\hline Total & 25 & 100 \\
\hline
\end{tabular}

Out of 25 maternal deaths, 12 women $(48 \%)$ died within 6 hours of admission and 6 women $(24 \%)$ died between 7-12 hours (Table 9).

Direct causes contributed to $68 \%$ of maternal deaths of which $32 \%$ were due to Hemorrhage (2 APH, $6 \mathrm{PPH}$ ), $16 \%$ eclampsia, sepsis and pulmonary embolism attributed to $12 \%$ and $8 \%$ respectively (Table 10). Amongst $32 \%$ of indirect causes of maternal death, heart disease, anaemia and cerebrovascular accident (CVA) accounted to $8 \%$ each. Jaundice and ARDS accounted to $4 \%$ each (Table 11). 
Table 5: Areas of residence.

\begin{tabular}{|lll|}
\hline Residence & Number & Percentage \\
\hline Urban & 3 & 12 \\
\hline Rural & 22 & 88 \\
\hline Total & 25 & 100 \\
\hline
\end{tabular}

Table 6: ANC registration.

\begin{tabular}{|lll|}
\hline ANC & Number & Percentage \\
\hline Booked & 4 & 16 \\
\hline Unbooked & 21 & 84 \\
\hline Total & 25 & 100 \\
\hline
\end{tabular}

Table 7: Distribution of cases according to parity.

\begin{tabular}{|lll|}
\hline Parity & Number & Percentage \\
\hline Primi & 7 & 28 \\
\hline Multi $(2-4)$ & 15 & 60 \\
\hline Grand multi $(\geq 5)$ & 3 & 12 \\
\hline Total & 25 & 100 \\
\hline
\end{tabular}

\section{DISCUSSION}

In the present study, maximum (68\%) number of deaths were in the age group <29years, of which $40 \%$ maternal deaths were in 19-24 years age and 28\% deaths in 25-29 years age group, which is similar to studies by Dogra et al and Ratan Das et al. ${ }^{6,7}$ With the prevailing custom of early marriage in rural areas, majority presented with pregnancy in early age group.

In the present study, 15 cases $(60 \%)$ were multigravida and $28 \%$ were primigravidas which is similar to studies by Dogra et al and Purandare et al. ${ }^{6,8}$ Too many pregnancies and less spacing between pregnancies may be attributed as a factor here.

In our study, majority (84\%) of maternal deaths were seen in unbooked cases, as has been also observed in Roy et al study. ${ }^{9}$ Highest mortality is observed among the marginalised and poor, who reside in remote and rural areas with limited access to health care services. ${ }^{7,10}$ A delay in accessing care can occur at three time points:

Three delay model ${ }^{3,11}$ :

1. Delay in decision making to seek care by a woman or her family when complication has aroused up.

2. Delay in reaching the health centre due to nonavailability or high cost of transport or long distance.

3. Delay in receiving care after reaching health centre.

Despite wide recognition of evidence based interventions and the availability of information and guidelines, major gaps remain in implementation.

In this study, $48 \%$ deaths occurred within 6 hours of hospital admission and $24 \%$ within $7-12$ hours which is similar to reports by Ratan Das et al and Purandare et al. ${ }^{7,8}$ Majority of the patients reach tertiary hospital quite late. So, strengthening of basic and comprehensive emergency obstetric care [EOC] at primary health centre level and first referral unit (FRU) could save many lives.

Table 8: State of pregnancy during death.

\begin{tabular}{|lll|}
\hline State of pregnancy & Number & Percentage \\
\hline First trimester & 0 & 0 \\
\hline Second trimester & 1 & 4 \\
\hline Third trimester & 1 & 4 \\
\hline Post-partum & 22 & 88 \\
\hline Post abortion & 1 & 4 \\
\hline Total & 25 & 100 \\
\hline
\end{tabular}

In this study, $88 \%$ deaths occurred in postpartum period. Similar results have also been reported by Dogra et al and Purandare et al. ${ }^{6,8}$ High number of deaths in postpartum period indicates the need for continuous vigilance in postpartum period and prompt action if problem arises. Intranatal care by skilled attendants and timely management and replacement of lost blood volume can reduce deaths in postpartum period. Skilled birth attendants and postnatal care barely reach half the population in need. ${ }^{10}$

Table 9: Time from admission to death.

\begin{tabular}{|lll|}
\hline Hours & Number & Percentage \\
\hline $0-6$ & 12 & 48 \\
\hline $7-12$ & 6 & 24 \\
\hline $12-24$ & 1 & 4 \\
\hline$>24$ & 6 & 24 \\
\hline Total & 25 & 100 \\
\hline
\end{tabular}

Direct causes contributed $68 \%$ of deaths. $32 \%$ were due to hemorrhage (2 APH, $6 \mathrm{PPH}$ ), 16\% due to eclampsia, sepsis and pulmonary embolism attributed to $12 \%$ and $8 \%$ respectively. Prevention and treatment of anaemia during pregnancy, early diagnosis of hypertension during pregnancy and good intranatal care can help in prevention of haemorrhage, which is the leading cause of death in our study.

Table 10: Direct causes of death.

\begin{tabular}{|lll|}
\hline Cause of death & Number & Percentage \\
\hline Eclampsia & 4 & 16 \\
\hline $\begin{array}{l}\text { Hemorrhage } \\
\text { (APH+PPH) }\end{array}$ & 8 & 32 \\
\hline Sepsis & 3 & 12 \\
\hline Pulmonary Embolism & 2 & 8 \\
\hline Total & 17 & 68 \\
\hline
\end{tabular}

The high maternal mortality due to eclampsia was among patients who had multiple seizures outside hospital and those without prenatal care. The close links among 
poverty, inequity, undernutrition and human deprivation have shown to reduce the potential for human development considerably. ${ }^{10}$

Table 11: Indirect causes of death.

\begin{tabular}{|lll|}
\hline Causes of death & Number & Percentage \\
\hline Heart disease & 2 & 8 \\
\hline CVA & 2 & 8 \\
\hline Renal failure & 0 & 0 \\
\hline Anaemia & 2 & 8 \\
\hline Jaundice & 1 & 4 \\
\hline ARDS & 1 & 4 \\
\hline Total & 8 & 32 \\
\hline
\end{tabular}

Amongst $32 \%$ of indirect causes of maternal deaths, heart disease, anaemia and cerebrovascular accident accounted to $8 \%$ each. Jaundice and ARDS accounted to $4 \%$ each.

It is important to look beyond survival of lives to issues of reducing morbidity and disability and improving long term outcomes of human development.

\section{CONCLUSIONS}

Most of the deaths could have been avoided with good antenatal, intranatal and postnatal care, early referral, quick, efficient and well equipped transport facilities, availability of adequate blood and blood components, and promotion of overall safe motherhood.

Despite wide recognition of evidence based interventions and the availability of information and guidelines, major gaps remain in implementation.

Maternal mortality can be averted by implementation of 3E's-Emergency obstetric care (EmOC), early risk screening and efficient obstetric service.

Analysis of every maternal death through maternal death audit should be carried out. Community participation is more necessary. Awareness of birth control measures, sex education in adolescence can reduce deaths due to septic abortion.

Maternal death audit will help in identifying the actual cause of maternal deaths and deficiencies in health care delivery system that might contribute in formulating preventive measures to reduce pregnancy related deaths.

\section{ACKNOWLEDGEMENTS}

We sincerely thank all staff of District Hospital, Gulbarga, Karnataka, India for their constant support and for providing facilities to conduct this study.

\section{Funding: No funding sources}

Conflict of interest: None declared

Ethical approval: The study was approved by the Institutional Ethics Committee

\section{REFERENCES}

1. Countdown to 2015 for maternal, newborn and child survival: Accountability for maternal, newborn and child survival. Geneva: Who Health Organization, 2013.

2. Trends in maternal mortality: 1990-2010 estimates developed by WHO, UNICEF, UNFPA and the World Bank, 2012.

3. Debalina D, Datta P. Maternal Mortality in India: Problems and strategies. Asian $\mathrm{J}$ Med Res. 2013;2(1):33-5.

4. Central Intelligence Agency Publications. The World Fact book. Country comparison: Maternal Mortality Rate.

5. Marmot M. Closing the health gap in a generation: the work of the commission on social determinants of health and its recommendations. Glob Health Promot. 2009;16(1):23-7.

6. Dogra P, Gupta K B. A study of maternal mortality at a tertiary institute. Obs and Gynaecol India. 2008;58:226-9.

7. Das R, Soumya B, Amitava M. Maternal mortality at a Teaching Hospital of Rural India:A retrospective study. Int J of Biomed \& Adv Res. 2014;5(2):114-7.

8. Purandare N, Singh A, Upadhyae S, Saraogi R M. Maternal mortality at a referral centre: a five year study. J Obstet gynaecol India. 2007;57:248-50.

9. Roy S, Singh A, Pandey A, Roy H et al. Maternal mortality in Apex Hospital of Bihar. J Obstet Gynaecol India. 2002;52:100-4.

10. Bhutta Z A, Black R E. Global Maternal, Newborn, and Child Health - so near and yet so far. N Engl $\mathbf{J}$ Med. 2013;369:2226-35.

11. Mullick SS, Serle E. Achieving millenium development goals 4 and 5: a snapshot of life in rural India. BJOG. 211;118(2):104-7.

Cite this article as: Biradar SV, Kerure RD, Biradar AV. Maternal mortality at Gulbarga district hospital, a tertiary care centre. Int J Reprod Contracept Obstet Gynecol 2015;4:1539-42. 